\title{
Protective role of Peanut oil in rats exposed to two different doses of gamma radiation that produced oxidative stress and bone injury
}

\author{
Tamer M. M. Saad and Amal A. A. Ammar \\ Medical and Radiation Research Department, \\ Nuclear Materials Authority,Cairo, Egypt
}

\begin{abstract}
Introduction: Exposure to ionizing radiation represents a genuine, increasing threat to mankind and our environment. The steadily increasing applications of radiation in clinical practice, industrial and agricultural activities, on top of residual radioactivity resulting from nuclear test explosions, have a measurable impact contributing to possible radiation hazards in humans. Control of radiation hazards is considered as one of the most important challenges in order to protect our lives from radiation damages.

The trans-3,4,5-trihydroxystibeneis a phyto-chemical present in peanuts and grapes with beneficial effects such as protection against cardiovascular disease and cancer prevention.

Purpose: The present study aims to clarify the role of peanut oil as a radioprotector in male albino rats against oxidative stress and bone injury induced by two different doses of gamma irradiation.

Material and Methods: Rats were subjected to a dose of 5 Gy (group 3) or 10 Gy ( group 4 ) ( single dose/ whole body ) in comparison with control group ( group 1 ). Prior to the two doses of gamma radiation, rats received peanut oil subcutaneously, $(0.75 \mathrm{ml} / \mathrm{kg})$ over one month period, on three days/week ( group 5 and 6 ). Group 2, rats received peanut oil subcutaneously, $(0.75 \mathrm{ml} / \mathrm{kg}$ ) as group 5 , but without exposure to radiation.
\end{abstract}

Results: The results showed that whole body gamma irradiation revealed significant acceleration in the level of lipid peroxide (MDA), with significant depletion in glutathione content (GSH), superoxide dismutase (SOD) and catalase (CAT) activities. Meanwhile. Also, the study showed significant increase in serum calcium with concomitant decrease in the bone calcium and significant increase in serum inorganic phosphorous concomitant with a decrease in bone phosphorous after radiation exposure.

Administration of peanut oil pre-irradiation has significantly ameliorated the radiation induced disturbance in all the investigated parameters.

Conclusion: Metabolism can be controlled to some extent by peanut oil administrated prior to irradiation.

Keywords: Peanut oil - Ionizing radiation - Antioxidants - Calcium - Phosphorous.

\section{Introduction}

Exposure to ionizing radiation represents a genuine, increasing threat to mankind and our environment. The steadily increasing applications of radiation in clinical practice, industrial and agricultural activities, on top of residual radioactivity resulting from nuclear test explosions, have a measurable impact contributing to possible radiation hazards in humans. Control of radiation hazards is considered as one of the most important challenges in order to protect our lives from radiation damages. 
Ionizing radiation provokes the decomposition reaction of water producing a variety of reaction oxygen species ( ROS ) (Sadani and Nadkami, 1997 ). ROS such as hydroxyl radicals $(\mathrm{OH})$, super-oxide anion radicals $\left(\mathrm{O}_{2}^{-}\right)$and hydrogen peroxide $\left(\mathrm{H}_{2} \mathrm{O}_{2}\right)$ are extremely reactive and react with the molecule of cell membranes that are composed of a double layer of lipids with proteins dispersed throughout ( Ho et al., 1998 ). Under normal conditions, there is a balance between the generation of ROS and the cellular antioxidant systems ( Timothy and Sharma, 1991 ). Exposure to ionizing radiation produces significant alterations in the oxidant activity in tissues and causes overproduction of ROS leading to oxidative damage of the lipids, proteins and DNA. The oxidation of polyunsaturated fatty acids in membrane induced by ROS is called lipid peroxidation (LPO). However, organisms have protective systems against ROS, like endogenous antioxidant enzymes. Superoxide dimutase ( SOD ), glutathione peroxidase ( GSH-Px ) and catalase (CAT) constitute primary enzymatic defense system ( Halliwell and Gutteridge, 1990 ). Reduced glutathione ( GSH ) is a major antioxidant that provides reducing equivalents for the GSH-Px ( Galeotti et al., 1991 ).

Calcium is one of the essential elements for normal functioning of an organism and its concentration in serum is kept within the narrow range of 8.7-10 $\mathrm{mg} / \mathrm{dl}$ ( Brozoska and Manuszko, 1996 ). Because of the importance of calcium in regulating vital cellular and tissue functions, the concentration of calcium ions in body fluids is regulated by an effective feedback control system including a $\mathrm{Ca}^{++}$transporting subsystem ( bone and kidney ), $\mathrm{Ca}^{++}$ sensing receptors and calcium regulating hormones: parathormone, calcitonine and 1,25-dihyroxy vit $\mathrm{D}_{3}$ ( Hurwitz, 1996 ). Parathormone and calcitonin positively regulate renal $1, \alpha$ hydroylase gene expression ( a key enzyme for $1,25(\mathrm{OH})_{3}$ $\mathrm{D}_{3}$ synthesis) which is found mainly in the kidneys ( Murayama et al., 1999 ).

Endo et al. ( 2000 ) suggested that 1,25 $(\mathrm{OH})_{3} \mathrm{D}_{3}$ has the potential to alleviate hypocalcemia, through the inhibition of bone resorption.

There is evidence that gamma radiation damages bone tissue via free radical attack on the collagen ( Akkus et al., 2005 ). Therapeutic doses of radiation have been shown to have deleterious consequences on bone health, occasionally causing osteoradionecrosis and spontaneous fractures ( Hamilton et al., 2006 ).

Juan et al. ( 2002 ) reported that trans-3,4,5trihydroxystibeneis a phyto-chemical present in peanuts and grapes with beneficial effects such as protection against cardiovascular disease and cancer prevention.

In the present study, several parameters were measured in male albino rats subjected to two different doses of gamma radiation, in order to clarify the role of peanut oil in protection against oxidative stress and bone injury.

\section{Material and Methods}

Male albino rats weighing $150 \pm 200 \mathrm{~g}$ were divided into six categories each with six animals. They were kept under the same controlled laboratory conditions of temperature, lighting and ventilation. All rats were fed on standard casein diet and water ad libitum.

i) Normal: Control group.

ii) Peanut oil group: Rats were received peanut oil subcutaneously, ( $0.75 \mathrm{ml} / \mathrm{kg}$ ) over one month period, on three days/week.

iii) $\gamma$ - irradiated group: Rats exposed to single dose (5 Gy) of whole body gamma irradiation was carried out using ${ }^{60} \mathrm{Co}$ 
source at National Centre for Radiation Research and Technology (NCRRT), Egypt. iv) $\gamma$ - irradiated group: Rats exposed to single dose (10 Gy) of whole body gamma irradiation was carried out using ${ }^{60} \mathrm{Co}$ source at National Centre for Radiation Research and Technology (NCRRT), Egypt. v) Peanut oil followed by $\gamma$ - irradiation group: Rats were received peanut oil subcutaneously, ( $0.75 \mathrm{ml} / \mathrm{kg}$ ) over one month period, on three days/week before exposed to single dose (5 Gy) of whole body gamma irradiation.

vi) Peanut oil followed by $\gamma$ - irradiation group: Rats were received peanut oil subcutaneously, ( $0.75 \mathrm{ml} / \mathrm{kg}$ ) over one month period, on three days/week before exposed to single dose (10 Gy) of whole body gamma irradiation.

\section{Radiation facilities:}

Irradiation of animals ( 5 and $10 \mathrm{~Gy}$ ) were performed at the National Centre for Radiation Research and Technology, Cairo, Egypt, using Cs-137 (Gamma Cell-40) giving a dose rate of $0.57 \mathrm{~Gy} / \mathrm{min}$ at the time of experiment.

\section{Biochemical analysis:}

After the experimentation period, rats were then decapitated, blood samples were collected from heart by using disposable syringes and transferred to both dry and EDTA sterile test tube, Lipid peroxidation as malondialdehyde (MDA), reduced glutathione content (GSH), super oxide dismutase activity (SOD) and catalase (CAT) were assayed in ETDA blood ( Yoshioka et al., 1979 ; Beutler et al., 1963 ; Minami and Yoshikawa, 1979 and Johansson and Borg, 1988, respectively), sera were separated for estimation of Calcium (Ca.) (Kaplan and Pesce, 1996), Phosphorous (P.) (Robert and Paul, 1937), Magnesium (Mg.) (Willis, 1959), alkaline phosphatase and acid phosphatase (Stephan et al., 1977 and Diana and Moss, 1961, respectively).
The right femur of each animal was cleaned from surrounding tissues, weighed and crushed, then completely homogenated in 3 $\mathrm{ml}$ distilled water and kept frozen at $-20^{\circ} \mathrm{C}$ till examination ( Kind and King, 1954 ). Samples, digested with concentrated nitric acid, were used for mineral estimation using an atomic absorption spectrophotometer.

\section{Results}

Table (1) presented MDA level, GSH content and SOD and CAT activities of rats exposed to two different doses of radiation with and without peanut oil administration.

Irradiated group recorded highly significant elevation $(\mathrm{P}<0.001)$ in MDA level, as compared with the corresponding nonirradiated group. In addition, it is evident from table (1) that irradiation caused significant depletion in GSH content and both SOD and CAT activities $(\mathrm{P}<0.001)$ on both doses (5Gy and 10Gy). Groups treated with peanut oil pre-irradiation turned the value of MDA level to its normal value, also peanut oil caused amelioration in GSH content and SOD and CAT activities.

The data in table (2) revealed that whole body gamma irradiation resulted in significant increase in serum calcium, inorganic phosphorous and magnesium contents with concomitant decrease in the bone $\mathrm{Ca}$., P. and $\mathrm{Mg}$. contents. Groups treated with peanut oil pre-irradiation resulted in sufficient amelioration in all investigated parameters.

Table (3) showed that, whole body gamma irradiation resulted in significant elevation in PTH and calcitonine with percentages of $73.9 \%$ and $63.1 \%$, respectively. Treated groups by peanut oil pre-irradiation turned the values of PTH and calcitonine to their normal values in the group irradiated by 5 Gy and showed amelioration in their values in the group irradiated by $10 \mathrm{~Gy}$.

The data in table (4) revealed that, irradiation caused significant decline in the 
activities of alkaline phosphatase in both serum and bone with percentage of $44.5 \%$ and $53.1 \%$, respectively. Also irradiation resulted in significant elevation in the activities of acid phosphatase in both serum and bone with percentage of $225 \%$ and $173 \%$, respectively. Groups treated with peanut oil pre-whole body gamma irradiation resulted in sufficient amelioration.

Table (1): Lipid peroxides as malondialdehyde (MDA) level, glutathione (GSH) content, superoxide dismutase (SOD) and catalase (CAT) activities in rats after whole body gamma irradiation and/or peanut oil administration.

\begin{tabular}{|c|c|c|c|c|}
\hline Group & $\begin{array}{c}\text { TBARS(MDA) } \\
(\mu \mathrm{mol} / \mathrm{l})\end{array}$ & $\begin{array}{c}\text { GSH } \\
(\mathrm{mg} / \mathrm{ml})\end{array}$ & $\begin{array}{c}\text { SOD } \\
(\mu \mathrm{g} / \mathrm{ml})\end{array}$ & $\begin{array}{c}\text { CAT } \\
(\mu \mathrm{g} / \mathrm{ml})\end{array}$ \\
\hline Control group & $\begin{array}{c}86.6 \pm 4.7 \\
(100 \%)\end{array}$ & $\begin{array}{c}45.5 \pm 3.1 \\
(100 \%)\end{array}$ & $\begin{array}{c}61.0 \pm 3.6 \\
(100 \%)\end{array}$ & $\begin{array}{c}23.6 \pm 1.1 \\
(100 \%)\end{array}$ \\
\hline Peanut oil G. & $\begin{array}{c}87.0 \pm 6.0 \\
(100.4 \%)\end{array}$ & $\begin{array}{c}46.0 \pm 3.5 \\
(101.0 \%)\end{array}$ & $\begin{array}{c}62.2 \pm 4.3 \\
(101.9 \%)\end{array}$ & $\begin{array}{c}24.0 \pm 1.8 \\
(101.6 \%)\end{array}$ \\
\hline $\begin{array}{c}\text { Irradiated G.(5 } \\
\text { Gy) }\end{array}$ & $\begin{array}{c}* * * \\
122.0 \pm 10.8 \\
(140.8 \%)\end{array}$ & $\begin{array}{c}* * * \\
31.3 \pm 2.6 \\
(68.7 \%)\end{array}$ & $\begin{array}{c}* * * \\
34.6 \pm 2.2 \\
(56.7 \%)\end{array}$ & $\begin{array}{c}* * * \\
16.0 \pm 1.0 \\
(66.0 \%)\end{array}$ \\
\hline $\begin{array}{c}\text { Irradiated G.(10 } \\
\text { Gy) }\end{array}$ & $\begin{array}{c}* * * \\
141.0 \pm 11.2 \\
(162.8 \%)\end{array}$ & $\begin{array}{c}* * * \\
28.2 \pm 1.7 \\
(61.9 \%)\end{array}$ & $\begin{array}{c}* * * \\
30.0 \pm 1.9 \\
(49.1 \%)\end{array}$ & $\begin{array}{c}* * * \\
11.2 \pm 0.86 \\
(46.6 \%)\end{array}$ \\
\hline $\begin{array}{l}\text { Peanut oil + } \\
\text { Irradiated G.(5 } \\
\text { Gy) }\end{array}$ & $\begin{array}{l}90.8 \pm 5.7 \\
(104.8 \%)\end{array}$ & $\begin{array}{c}40.4 \pm 3.6 \\
(88.7 \%)\end{array}$ & $\begin{array}{c}54.4 \pm 4.1 \\
(89.1 \%)\end{array}$ & $\begin{array}{c}* \\
20.0 \pm 1.4 \\
(84.7 \%)\end{array}$ \\
\hline $\begin{array}{c}\text { Peanut oil + } \\
\text { Irradiated G.(10 } \\
\text { Gy) }\end{array}$ & $\begin{array}{c}102.6 \pm 6.8 \\
(118.4 \%)\end{array}$ & $\begin{array}{c}* * \\
33.0 \pm 1.9 \\
(72.5 \%)\end{array}$ & $\begin{array}{c}* * \\
48.3 \pm 2.8 \\
(79.1 \%)\end{array}$ & $\begin{array}{c}* * \\
18.3 \pm 1.0 \\
(77.5 \%)\end{array}$ \\
\hline
\end{tabular}

G. = group

S. serum

Each value is the mean of 6 rats \pm S.E.

Significant difference from control at $* \mathrm{P}<0.05$, ** $\mathrm{P}<0.01$ and $* * * \mathrm{P}<0.001$ as judged by Student t-test. 
Table (2): Calcium (Ca), phosphorous (P) and magnesium (Mg) (both in serum and bone) concentrations in rats after whole body gamma irradiation and/or peanut oil administration.

\begin{tabular}{|c|c|c|c|c|c|c|}
\hline Group & $\begin{array}{c}\text { S. Ca. } \\
\text { (mg/dl) }\end{array}$ & $\begin{array}{c}\text { Bone Ca. } \\
\text { (g/gwt) }\end{array}$ & $\begin{array}{c}\text { S. P. } \\
\text { (mg/dl) }\end{array}$ & $\begin{array}{c}\text { Bone P. } \\
\text { (g/gwt) }\end{array}$ & $\begin{array}{l}\text { S. Mg. } \\
\text { (mg/dl) }\end{array}$ & $\begin{array}{c}\text { Bone Mg. } \\
\text { (g/gwt) }\end{array}$ \\
\hline $\begin{array}{l}\text { Control } \\
\text { group }\end{array}$ & $\begin{array}{c}8.6 \pm 0.32 \\
(100 \%)\end{array}$ & $\begin{array}{c}0.6 \pm 0.03 \\
(100 \%)\end{array}$ & $\begin{array}{c}3.8 \pm 0.21 \\
(100 \%)\end{array}$ & $\begin{array}{c}88.0 \pm 5.4 \\
(100 \%)\end{array}$ & $\begin{array}{c}3.4 \pm 0.16 \\
(100 \%)\end{array}$ & $\begin{array}{c}105.0 \pm 6.4 \\
(100 \%)\end{array}$ \\
\hline $\begin{array}{c}\text { Peanut oil } \\
\text { G. }\end{array}$ & $\begin{array}{c}8.94 \pm 0.4 \\
(103.9 \%)\end{array}$ & $\begin{array}{c}0.63 \pm 0.02 \\
(105.0 \%)\end{array}$ & $\begin{array}{l}4 . .0 \pm 0.3 \\
(105.2 \%)\end{array}$ & $\begin{array}{c}86.5 \pm 4.4 \\
(98.2 \%)\end{array}$ & $\begin{array}{c}3.2 \pm 0.2 \\
(94.1 \%)\end{array}$ & $\begin{array}{c}100.0 \pm 7.1 \\
(95.2 \%)\end{array}$ \\
\hline $\begin{array}{c}\text { Irradiated } \\
\text { G.(5 Gy) }\end{array}$ & $\begin{array}{c}* * \\
12.9 \pm 0.8 \\
(150.0 \%)\end{array}$ & $\begin{array}{c}* * \\
0.45 \pm 0.04 \\
(75.0 \%)\end{array}$ & $\begin{array}{c}* * * \\
6.3 \pm 0.36 \\
(165.7 \%)\end{array}$ & $\begin{array}{c}* * * \\
48.5 \pm 3.4 \\
(55.1 \%)\end{array}$ & $\begin{array}{c}* * * \\
5.6 \pm 0.36 \\
(164.7 \%)\end{array}$ & $\begin{array}{c}* * \\
78.5 \pm 5.9 \\
(74.7 \%)\end{array}$ \\
\hline $\begin{array}{l}\text { Irradiated } \\
\text { G. }(10 \mathrm{~Gy})\end{array}$ & $\begin{array}{c}* * * \\
19.4 \pm 0.7 \\
(225.5 \%)\end{array}$ & $\begin{array}{c}* * * \\
0.29 \pm 0.02 \\
(43.3 \%)\end{array}$ & $\begin{array}{c}* * * \\
9.4 \pm 0.54 \\
(247.3 \%)\end{array}$ & $\begin{array}{c}* * * \\
32.3 \pm 2.2 \\
(36.7 \%)\end{array}$ & $\begin{array}{c}* * * \\
6.7 \pm 0.7 \\
(197.0 \%)\end{array}$ & $\begin{array}{c}* * * \\
56.0 \pm 4.1 \\
(53.3 \%)\end{array}$ \\
\hline $\begin{array}{c}\text { Peanut oil } \\
+ \\
\text { Irradiated } \\
\text { G. }(5 \text { Gy) }\end{array}$ & $\begin{array}{c}9.3 \pm 0.64 \\
(108.1 \%)\end{array}$ & $\begin{array}{c}* \\
0.52 \pm 0.03 \\
(86.6 \%)\end{array}$ & $\begin{array}{c}4.5 \pm 0.23 \\
(118.4 \%)\end{array}$ & $\begin{array}{c}79.0 \pm 4.3 \\
(89.7 \%)\end{array}$ & $\begin{array}{c}3.1 \pm 0.21 \\
(91.1 \%)\end{array}$ & $\begin{array}{c}96.3 \pm 7.3 \\
(91.7 \%)\end{array}$ \\
\hline $\begin{array}{c}\text { Peanut oil } \\
+ \\
\text { Irradiated } \\
\text { G.(10 Gy) }\end{array}$ & $\begin{array}{l}10.2 \pm 0.7 \\
(118.6 \%)\end{array}$ & $\begin{array}{c}* * \\
0.42 \pm 0.02 \\
(70.0 \%)\end{array}$ & $\begin{array}{c}* * \\
5.2 \pm 0.32 \\
(136.8 \%)\end{array}$ & $\begin{array}{c}* * \\
61.6 \pm 4.8 \\
(70.0 \%)\end{array}$ & $\begin{array}{c}* * \\
4.8 \pm 0.38 \\
(141.1 \%)\end{array}$ & $\begin{array}{c}* \\
88.0 \pm 6.4 \\
(83.8 \%)\end{array}$ \\
\hline
\end{tabular}

Legend as in Table (1). 
Table (3): Parathormone (PTH) and calcitonin levels in rats after whole body gamma irradiation and/or peanut oil administration.

\begin{tabular}{|c|c|c|}
\hline Group & $\begin{array}{c}\text { PTH } \\
(\mathbf{p g} / \mathbf{m l})\end{array}$ & $\begin{array}{c}\text { Calcitonin } \\
(\mathbf{p g} / \mathbf{m l})\end{array}$ \\
\hline Control G. & $23.0 \pm 1.1$ & $3.8 \pm 0.17$ \\
& $(100 \%)$ & $(100 \%)$ \\
\hline Peanut oil & $22.8 \pm 1.4$ & $3.9 \pm 0.2$ \\
G. & $(99.1 \%)$ & $(102.6 \%)$ \\
\hline Irradiated & $* *$ & $* *$ \\
G.(5 Gy) & $31.2 \pm 2.2$ & $5.0 \pm 0.32$ \\
& $(134.4 \%)$ & $(131.5 \%)$ \\
\hline Irradiated & $* * *$ & $* * *$ \\
G.(10 Gy) & $40.0 \pm 2.9$ & $6.2 \pm 0.39$ \\
& $(173.9 \%)$ & $(163.1 \%)$ \\
\hline Peanut oil + & & $4.1 \pm 0.28$ \\
Irradiated & $24.6 \pm 2.0$ & $(107.8 \%)$ \\
G.(5 Gy) & $(106.9 \%)$ & $* *$ \\
\hline Peanut oil + & $* *$ & $5.1 \pm 0.41$ \\
Irradiated & $30.0 \pm 2.6$ & $(134.2 \%)$ \\
G.(10 Gy) & $(130.4 \%)$ & \\
\hline
\end{tabular}

Legend as in Table (1). 
Table (4): Alkaline phosphatase (Alk. Ph.) and Acid phosphatase (Acid Ph.) (both in serum and bone) activities in rats after whole body gamma irradiation and/or peanut oil administration.

\begin{tabular}{|c|c|c|c|c|}
\hline Group & $\begin{array}{c}\text { S. Alk.Ph. } \\
\text { (KAU/dl) }\end{array}$ & $\begin{array}{c}\text { Bone Alk. Ph. } \\
\text { (KAU/d) }\end{array}$ & $\begin{array}{c}\text { S. Acid Ph. } \\
\text { (KAU/d) }\end{array}$ & $\begin{array}{c}\text { Bone Acid Ph. } \\
\text { (KAU/dl) }\end{array}$ \\
\hline Control G. & $58.4 \pm 4.0$ & $45.3 \pm 3.2$ & $3.2 \pm 0.18$ & $9.7 \pm 0.6$ \\
& $(100 \%)$ & $(100 \%)$ & $(100 \%)$ & $(100 \%)$ \\
\hline Peanut oil G. & $59.0 \pm 3.4$ & $46.1 \pm 3.0$ & $3.4 \pm 0.2$ & $9.8 \pm 0.71$ \\
& $(101.0 \%)$ & $(101.7 \%)$ & $(106.2 \%)$ & $(101.0 \%)$ \\
\hline Irradiated G.(5 & $* * *$ & $* *$ & $* * *$ & $*$ \\
Gy) & $34.3 \pm 2.0$ & $34.0 \pm 2.1$ & $5.6 \pm 0.38$ & $12.2 \pm 0.94$ \\
& $(58.7 \%)$ & $(75.0 \%)$ & $(175.0 \%)$ & $(125.7 \%)$ \\
\hline Irradiated G.(10 & $* * *$ & $* * *$ & $* * *$ & $16.8 \pm 0.98$ \\
Gy) & $26.0 \pm 1.8$ & $23.8 \pm 1.1$ & $7.2 \pm 0.43$ & $(173.1 \%)$ \\
\hline Peanut oil + & $(44.5 \%)$ & $(53.1 \%)$ & $(225 \%)$ & $10.2 \pm 0.84$ \\
Irradiated G.(5 & $52.2 \pm 3.9$ & $40.0 \pm 3.0$ & $3.9 \pm 0.24$ & $(105.1 \%)$ \\
Gy) & $(89.3 \%)$ & $(88.3 \%)$ & $(121.8 \%)$ & $* *$ \\
\hline Peanut oil + & $* *$ & $*$ & $* * *$ & $13.4 \pm 0.76$ \\
Irradiated G.(10 & $44.5 \pm 3.2$ & $37.5 \pm 2.4$ & $4.9 \pm 0.28$ & $(138.1 \%)$ \\
Gy) & $(76.1 \%)$ & $(82.7 \%)$ & $(158 \%)$ & \\
\hline
\end{tabular}

Legend as in Table (1).

\section{Discussion}

The use of ionizing radiation to kill tumor cells is a common treatment for cancer. Exposure to ionizing radiation causes radiolysis of water in tissues leading to generation of ROS, which are known to affect the antioxidant defense system and induce LPO ( Riley, 1994 ). The consequence of this increased free radical generation and imbalances in antioxidant defense is oxidative stress, which leads to oxidative damage, resulting in increased lipid peroxide levels. TBARS is used as an indicator of the rate of LPO which is accepted as tissue chain reaction (Ohkawa et al., 1979 ).

Gamma rays act either directly or by secondary reactions to produce biochemical lesions that initiate series of physiological symptoms. Ionizing radiation is known to induce oxidative stress through the generation of reactive oxygen species (ROS) resulting in imbalance of the prooxidant and antioxidant activities, ultimately resulting in cell death ( Srinvasan et al., 2006 ). Numerous attempts were made to investigate different means for controlling and protection from radiation hazards using chemical, physical and biological means.

The results revealed significant acceleration in the oxidation of lipid associated with depletion in GSH level due to radiation exposure. It was argued that the oxidant/antioxidant imbalance due to oxidative stress is the main cause of the excessive formation of peroxides as MDA ( Oliinyk et al., 2001 ). This response of antioxidant activity was attributed to the acute period of inflammatory processes developed during radiation exposure, which is characterized by the accumulation of lipid 
peroxidation products ( Davydov et al., 2000 ). The decrease in antioxidant enzyme activities and increase in the free radicals may be the main cause of irradiation induced peroxidation and damage of cell activities. The significant acceleration in lipid peroxidation is attributed to peroxidation of the membrane unsaturated fatty acids due to free radicals propagation concomitant with the inhibition in biooxidase activity ( Pollack and Leeuwenburgh, 2000 ).

According to the present findings, peanut oil provided subcutaneously protects against biological effects caused by gamma irradiation. This protection may be due to its stimulating effects on antioxidant system or ability to prevent and/or react with the free radicals to convert them into non-harmful forms. Due to vitamin E content of peanut oil, it prevents lipid peroxidation chain reaction in the cell membrane. It was suggested that vitamin $\mathrm{E}$ undergoes this in two ways : by interaction with unsaturated fatty acid and protecting the polypeptide chain of proteins ( Cadenas and Barja, 1999 and Muazzez et al., 2007 ).

A marked increase was noted in serum calcium content with concomitant decrease in the bone calcium content of irradiated group. The observed increase may be attributed to an increase in parathyroid hormone as mentioned by Fujwara et al. (1994), and/or increase in the intestinal brush border membrane cation permeability ( Hizhnyak, 1997 ). On the other hand, the decline of bone calcium content may be due to bone demineralization after irradiation as reported by Fukunda and Lida (1999).

The reduction in the calcium disturbances following irradiation in the peanut preirradiated group may be due to the vitamin $\mathrm{E}$ content of peanut oil providing a suitable level of zinc (Farag, 1999 ), which enhances 1,25 $(\mathrm{OH})_{3} \mathrm{D}_{3}$ stimulated bone metabolism and/or protection against free radicals generated by irradiation ( Glscott $\boldsymbol{e t}$ al., 1996 and Yao et al., 2005 ).

An increase in serum inorganic phosphorus concomitant with a decrease in bone phosphorous in irradiated groups is in accordance with the results of Filipov $\boldsymbol{e t}$ al. (1991) and may be due to bone demineralization after irradiation, and/or the destruction or arrest of the activities of bone cells such as osteoblasts. The administration of peanut oil pre-irradiation seems to reduce radiation damage possibly due to its antioxidant effect (Chen et al., 2002 ).

The increase in serum content and concomitant decrease in bone content of magnesium may be a result of increased levels of parathyroid hormones, which stimulate magnesium absorption from the gut ( Hulter and Peterson, 1984 ) and release of magnesium ion from bone ( Zofokova and Kancheva, 1995 ), as well as acceleration of bone resorption ( Chavelly and Rizzoli, 1999 ). Retention of magnesium levels to near normal in the peanut oil pre-treated group may be attributed to the protection of the sulfhydryl group $(\mathrm{SH})$ from oxidative damage through inhibition of peroxidation of membrane lipids of rats ( Upasni and Balarman, 2001 ).

Whole body gamma irradiation produced elevation in the level of rat serum parathyroid hormone relative to the control group, a result which may indicate parathyroid odenoma and carcinoma caused by irradiation ( Christmas et al., 1988 ). This increase may also be attributed to defective calcium absorption mechanism resulting from impaired hepatic and renal function, and consequently the formation of active metabolite, vitamin D ( Sotornik, 1997 ). The reduction in parathyroid damage following radiation in the peanut oil pretreated group could be due to presence of phytosterol, which have anticancer effect ( Awad et al., 2000 ).

The increased calcitonin in the irradiated group may result from a feedback mechanism to overcome the increase in calcium and parathormone levels ( Fujiwara et al., 1994 ). The alteration in calcitonin level in the peanut oil protected group may be due to antioxidant activity, which tends to improve bone formation and 
decrease bone resorption, thus, reduce serum calcium levels ( Arjmandi et al., 2002 ).

The observed decline in serum and bone alkaline phosphatase in the irradiated group may be due to early decline in the intestinal alkaline phosphatase isoenzyme activity ( Stephan et al., 1977 ). This decrease may also be attributed to a transitory reduction in the release of alkaline phosphatase to the enzymatic circulation by rapidly metabolizing cell ( Geraci et al., 1991 ), and/or injury to the intestinal mucosa after irradiation as mentioned by Faheim et al. (1993). The decrease in bone alkaline phosphatase in the irradiated group implies bone deformity resulting from an excess of resorption over formation ( Aitsula, 1986 ), as bone alkaline phosphatase is more specific as an important bone formation marker than is total alkaline phosphatase ( Khosla et al., 1999).

The amelioration in alkaline phosphatase activity resulting from peanut oil preirradiation may be due to a beneficial effects on membrane permeability leading to the maintenance of a higher level in serum ( Juan et al., 2002 ). In addition, the presence of strong antioxidant resveratol may increase alkaline phosphatase in osteoblastic cells to stimulate bone resynthesis, a view which is in accordance with Mizutani et al. ( 1998 ) and Xu et al. ( 2010 ).

The elevated serum and bone acid phosphatase levels in the irradiated group may be attributed to the breakdown of lysosomal membranes by the lipid peroxidation effect of radiation, resulting in release of the enzyme ( Kumar et al., 2003 ). In addition, irradiation may lead to lesion in the developing lysosomal membranes, through the action of oxygen free radicals, increasing membranes permeability and allowing acid phosphatase to escape ( Becciolni et al., 1982 ). The elevated bone acid phosphatase may be due to the release of enzyme from osteoplast lysosomes as a result of bone resorption after irradiation ( Aitsula, 1986 ). The maintenance of more normal serum and bone acid phosphatase levels in the peanut oil protected group should be attributed to the free radical scavenging ability of vitamin $\mathrm{E}$, which can suppress bone resorption and prevent membrane lesions.

\section{Conclusions}

It could be concluded that, administration of peanut oil before whole body irradiation resulted in sufficient amelioration against radiation effects on the biochemical aspects examined in the present study.

\section{References}

-Aitsula K. (1986): Bone tissue response to irradiation and treatment model of mandibular irradiation injury. An experimental and clinical Acta., 428: 1-54.

-Akkus O, Belaney R and Das P. (2005): Free radical scavenging alleviates the biochemical impairment of gamma radiation sterilized bone tissue. Journal of Orthopaedic Research, 23 (4): 838-845.

-Arjmandi B, Juma S, Beharka A, Bapna M, Akhter M, and Meydani S. (2002): Vitamin E improves bone quality in the aged but not in young adult male mice. Journal of Nutrition and biochemistry, 13 (9): 543-545.

-Awad A B, Chan K C, Downie A C, and Fink C S. (2000): Peanut as a source of betasitosterol, a sterol with anticancer properties. Nutrition and Cancer, 36 (2): 238-241.

-Becciolin A, Benucci A, Porciani S, Nardino A, and Lanini A. (1982): Dipeptidase activity in the small intestine after irradiation at different times of day. Strahlentherapie, 158 (6): 368-374.

-Beutler E, Daron O, and Kelly D M. (1963): Improved method of the determination of blood glutathione. J. Lab. Clin. Med., 61 (5): 882-888.

-Brozoska M, and Monuszko J. (1996): Homeostasis of calcium in the organism. Polski Merkuriusz Lekaraski, 1 (5): 363-365.

-Cadences S, and Barja G. (1999): Resveratrol, melatonin, vitamin $\mathrm{E}$ and $\mathrm{PBN}$ protect against renal oxidative DNA damage by the kidney carcinogen. Free Radical Biology and Medicine, 26 (11-12): 1531-1537.

-Chavelly T, and Rizzoli R. (1999): Bone and hormone effects of parathyroid hormones on the bone. Prease Medicale, 28 (10): 547-553.

-Chen R S, Wu P L, and Chiou R Y. (2002): Peanut oil as a source of reseratol. Journal of Agriculture Food Chemistry, 50 (60): 16651669. 

-Christmas T J, Chappie C R, Nobble I G, Milory E J, and Cowie A G. (1988): Hyperparathyrodism after neck irradiation. British Journal of Surgery, 75 (9): 873-874.

-Davydov V L, Kisel M A, Shdyro O I, and Iurkova I L. (2000): Chelating and free radical scavenging mechanism of inhibitory action of rutin in lipid peroxidation. Radiation Biology and Radioecology, 40 (4): 382-386.

-Diana M, and Moss D W. (1961): Spectrofluorimetric determination of acid phosphatase activity. Clinical Chemistry Acta, 6 (3): 307-315.

-Endo K, Katsuumata K, Hirata M, Massaki T, Kubodera N, Nakamura T, and Ogata E. (2000): 1,25-dihyroxy vitamin as well as its analogue lower blood calcium through inhibition of bone resorption in hypercalcemic rats with contious parathyroid hormone-related peptide infusion. Journal of Bone Mineral Research, 1: 175-181.

-Faheim F A, Rushdy H M, Yousri R M, and Abady M I. (1993): Some biochemical aspects of the protective effects of strontium chloride on gamma irradiated rats. Biometals, 6 (3): 163 170 .

-Farag E K. (1999): Interaction between supplemented selenium and/or vitamin $\mathrm{E}$ and $\mathrm{Mn}, \mathrm{Zn}, \mathrm{Cu}$ in schistosoma infected mice. Journal of Egyptian Society of Parasitology, 29 (2): 517-529.

-Filipov Z H, Bodurov N, and Bochukov A. (1991): Effects of UV-irradiation autologus blood on various morphological biochemical blood indices and phagocytic activity of the leukocytes in cattle. Experimental Hematology, 19 (8): 742-748.

-Fujwara S, Sposto R, Shiraki M, and Sasaki H. (1994): Levels of parathyroid hormone and calcitonine in serum among atomic bomb survivois. Radiation Research, 137: 96-103.

-Fukuda S, and Lida H. (1999): Effects of clinostat-microgravity and heavy particle radiation in bone and calcium metabolism in rats. Journal of Japanese Bone Morphormetry, 9: 3544.

-Galeotti T, Masotti L, Borrello S, and Casali E. (1991): Oxy-radical metabolism and control of tumor growth. Xenobiotica., 21: 1041-1051.

-Geraci J P, Mariano M S, and Jackson K L. (1991) : Hepatic radiation injury in rats. Radiation Research, 125 (1): 65-72.

-Glscott P A, Gilfor E, Serroni A, and Farber J L. (1996): Independent antioxidant action of vitamin $\mathrm{E}$ and $\mathrm{C}$ in cultured rat hepatocyted with ally alcohol. Biochemical Pharmacology, 52: 1245-1252.

-Halliwell B, and Gutteridge J M. (1990): Role of free radicals and catalytic ions in human disease, an overview. Metals Enzymology, 186: 1-85.

-Hamilton S, Pecaut M, Gridley D, Travis N, Bandstr E, Willey J, Nelson G, and Bateman T. (2006): Amurine model for bone loss from therapeutic and space-relevant source of radiation. Journal of Applied Physiology, 101 (3): 789-793.

-Hizhnyak S V. (1997): The effect of X-ray irradiation on ionized calcium concentration in enterocytes of rat small intestine. Journal of Scientific Research, 4: 101-105.

-Ho Y S, Magnenat J L, Gargano M, and Cao J. (1998): The nature of antioxidant defense mechanisms: a lesson from transgenic studies. Environ. Health Presp., 106: 1219-1228.

-Hulter H N, and Peterson J C. (1984): Renal and system magnesium metabolism during chronic continues parathormone infusion in normal subjects. Metabolism, 33: 662-666.

-Hurwitz S. (1996): Homeostatic control of plasma calcium concentration. Critical Reviews in Biochemistry and Molecular Biology, 31 (1): 41-100.

-Johansson L H, and Borg L A. (1988): Determination of catalase activity. Analytical Biochemistry, 174: 331-335.

-Juan E E, Vinadradell M P, and Planass J M. (2002): The daily oral administration of high doses of transresveratol to rats for 28 days is not harmful. Journal of Nutrition, 132 (2): 257-260.

-Kaplan L A, and Pesce A J. (1996): Estimation of Calcium both in serum and bone. Clinical Chemistry, Mosby Ed.

-Khosla S, Meltoo L, and Riftgfc B X. (1999): Osteoporosis: gender differences and similarities. Lupus, 8 (5): 393-396.

-Kind P R, and King E I. (1954): Estimation of plasma phophatase by determination of hydrolysed phenol with amino antipyrine. Journal of Clinical Pathology, 7: 322-326.

-Kumar M, Sharma K M, Saxena S P, and Kumar A. (2003): Radioprotective effect of panax gindseng on the phosphatases and lipid peroxidation level in testes of Swiss Albino Mice. Biological Pharmacy Bulleten, 26 (3): 308-312.

-Minami M, and Yoshikawa H. (1979): A simplified assay method of SOD activity of clinical use. Clinical Chemistry Acta, 9: 337342. 
-Mizutani K, Ikeda K, Kawai Y, and Yamori Y. (1998): Resveratol stimulates the proliferation and differentiation of osteoblastic $\mathrm{MC}_{3}$ Ts-Ei cells. Biochemical and Biophysical Research Community, 253 (3): 859-863.

-Muazzez G, Omit Z, Sibel E, Aydin C, and Funda E. (2007): The hepatotoxic effects of deep-fried sunflower oil on rat livers. Adv. Molecular Medicine, 3 (1):35-40.

-Murayama A, Makeyuma K, Kitanaka S, Kodera Y, Kawaguchi Y, Hosoya T, and Kato S. (1999): Positive and negative regulations of renal 25-hydroxy vitamin $\mathrm{D}_{3}$ alpha hydroxylase gene by parathyroid hormone, calcitonin and $1,25 \quad(\mathrm{OH}) \quad 2 \quad \mathrm{D}_{3} \quad$ in intact animals. Endocrinology, 140 (5): 2224-2231.

-Ohkawa H, Ohishi N, and Yagi K. (1979): Assay for lipid peroxides in animal tissues by thiobarbituric acid reaction. Anal Biochemistry, 95 : 351-358.

-Oliinyk B, Barbai A, Oliinyk S, and Horchakova O. (2001): Effect of spleenosid on lipid peroxidation process and glutathione antioxidant system in rats exposed to fractionated radiation. Journal UKR BioKhim ZH. Zool., 73 (1): 73-77.

-Pollack M, and Leeuwenburgh C. (2000): Molecular mechanisms of oxidative stress in aging: free radicals, aging, antioxidants and disease. Ed, Elsevier Science B. V., 30: 881-923. -Riley P A. (1994): Free radicals in biology, oxidative stress and the effects of ionizing radiation. Int. Journal of Radiation Biology, 65 : 27-33.

-Rober L, and Paul I. (1937): Quantitative drope analysis, Determination of phosphorous, $\mathbf{3}$ (1): 221-227.

-Sandani G R, and Nadkami G D. (1997): Changes in lipid peroxide levels and the activity of reactive oxygen scavenging systems in thyroid tissue after exposure to radioactive iodine in rats. Thyroid, 7: 937-941.
-Sotornik I. (1997): Relation between parathormone and 1,25 -dihydroxy vitamin D in chronic kidney failure. Vnitmi Lekarstvi, 43 (9): 616-619.

-Srinvasan M, Sudheer A R, Pillall K R, Kumar P R, Sudhakaran P, and Menon V. (2006): Influence of ferulic acid on gamma radiation induced DNA damage, lipid peroxidation and antioxidant status in primary culture of isolated rat hepatocytes. Toxicology, 228 (2-3): 249-258.

-Stephan J, Havranex T, and Jojkova K. (1977): Serum alkaline phosphatase as indicators of radiation damage in rats. Radiation Research, 70 : 406-414.

-Timoth R R, and Sharma H M. (1991): Free radicals in health and disease. Indian Journal of Clinical Practes, 2: 15-25.

-Upsani C D, and Balarman R. (2001): Effect of vitamin $\mathrm{E}$, vitamin $\mathrm{C}$ and spirulina on the levels of membrane bound enzymes and lipids in some organs of rats exposed to lead. Indian Journal of Pharmacology, 33 : 185-191.

-Willis J B. (1959): Determination of magnesium on blood serum by atomic absorption spectroscopy. Nature, 184 : 186-187.

-Xu Q, Zhao Y, Zhi J, and Yan Z. (2010): Effect of peanut oil on expression of NGF and chat in hippocampal CA1 area of type 2 diabetic rats. Chinese J. of Comprative Medicine, 4 (2): 38-45.

-Yao Y, Zhang R, and Zhi J. (2005): Comparison of peanut oil and olive oil in nutritional value. J. China Oil and Fats, 6 (1): 101-108.

-Yoshioka T, Kawada K, Shimada T, and Mori M. (1979): Lipid peroxidation in maternal and cord blood and protective mechanism against activated oxygen toxicity in the blood. Am. J. Obstet. Gynecology, 135: 372-376.

-Zofokova I, and Kancheva R L. (1995): The relation between magnesium and calciotrpic hormones. Magnesium Research, 8 : 77-84. 


\section{الدور الوقائى لزيت الفول السودانى فى الجرذان المعرضه لجرعتين مختلفتين من

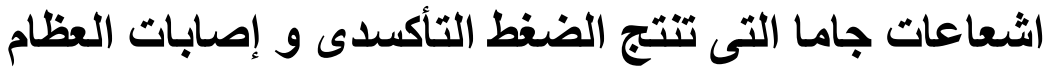

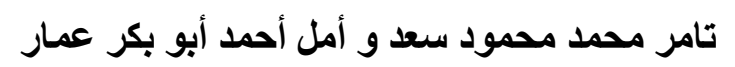

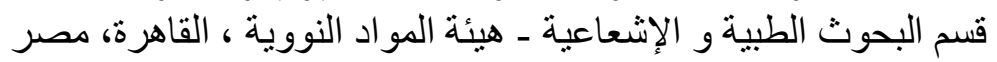

يهذف هذا البحث إلى توضيح دور زيت الفول السودانى كو اقى إنعاعى فى ذكور جرذان الألينو،

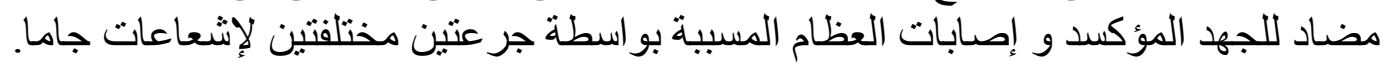

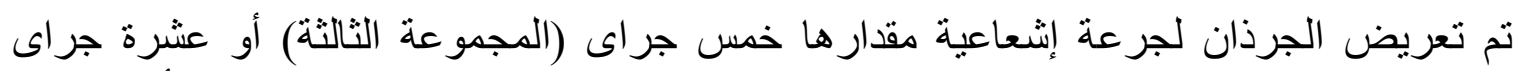
(المجمو عة الر ابعة) (جر عة منفرده/الجسم كلة) بالمقارنة بمجمو عة ضابطة (المجمو عة الأولى).

قد أعطيت الجرذان زيت الفول السودانى عن طريق الحقن تحت الجلد قبل نعريضها للجر عتين

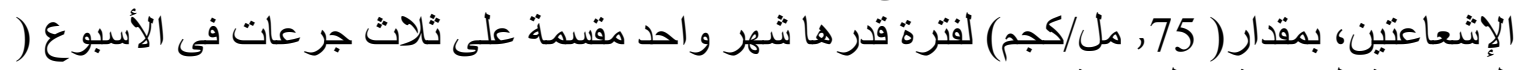

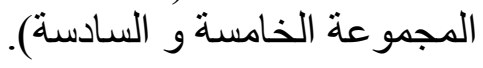

قد أعطيت الجرذان زيت الفول السودانى عن طريق الحقن تحت الجلا بجرعة مقدارها (75, مل/كجم)، و لكن بدون تعريضها للإثعاع ( الهجمو عة الثانية).

تم قياس بعض مستويات أنظمة مضادات الأكسدة فى مصل الدم و الدم مثل: مستوى أكسدة الدهون

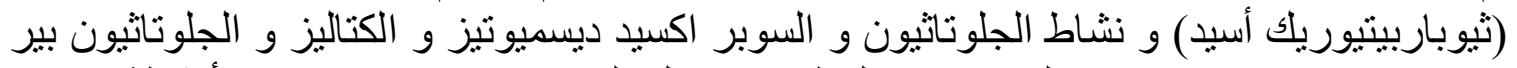

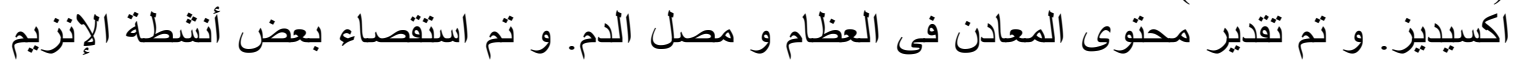

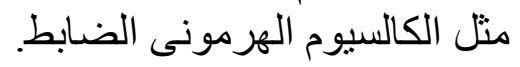

يمكن التحكم فى التنثيل الغذائى إلى حد ما عن طريق إعطاء زيت الفول السوداني قبل التثنعيع. 